\title{
PELATIHAN APLIKASI MICROSOFT EXCEL 2013 BAGI GURU-GURU SLB PAMBUDI DHARMA
}

\author{
Supriady $^{1}$, I Made Yadi Dharma ${ }^{2}$ \\ D3 Teknik Informatika, Politeknik Pos Indonesia \\ email: yadi.ipchi@gmail.com \\ D3 Teknik Informatika, Politeknik Pos Indonesia \\ email: madeyadi81@gmail.com
}

\begin{abstract}
Abstrak
Pelatihan ini merupakan pelatihan lanjutan tahun sebelumnya yaitu pelatihan MS Word pada tahun 2017, dan tahun ini akan dilanjutkan dengan pelatihan MS Excel. Disamping mengajar, guru juga mempunyai tugas-tugas administrasi yang dikerjakan setiap harinya. Untuk pekerjaan administrasi sekolah, surat menyurat ataupun keperluan pekerjaan ke Kantor Dinas, diantaranya menggunakan komputer yang dalam hal ini adalah Microsoft Excel.

Disamping membahas materi micrisoft excel secara umum, pelatihan ini juga akan di sesuaikan dengan tugas rutin guru-guru di sekolah, sehingga diharapkan pengetahuan yang didapat akan menambah semangat dalam menulis dan meningkatkan kinerja guru-guru dalam melaksanakan kegiatan rutinitasnya.

Penulis berharap dengan adanya pelatihan ini, akan membantu pihak sekolah SLB Pambudi Dharma dalam pemanfaatan teknologi komputer yang pada akhirnya dapat meningkatkan profesionalisme para guru-guru itu sendiri. Proses pelaksanaan pelatihan ini dilaksanakan di Sekolah Luar Biasa Pambudi Dharma.
\end{abstract}

Kata Kunci: Pelatihan, Sekolah, Teknologi, Komputer

\section{PENDAHULUAN}

\subsection{Analisis Situasi}

SLB Pambudi Dharma adalah sebuah Sekolah Luar Biasa yang berada di wilayah Cimahi Jawa Barat, tepatnya di Jalan Kolonel Masturi Cimahi. Jarak dari Politeknik Pos Indonesia ke lokasi Mitra kurang lebih $13 \mathrm{KM}$.

Sekolah SLB Pambudi Dharma saat ini sudah menggunakan komputer dan internet dalam aktivitasnya sehari-hari. di Ruang Kepala Sekolah terdapat 1 unit komputer sebagai fasilitas Kepala Sekolah yang juga digunakan untuk pekerjaan administrasi sekolah oleh guru-guru lainnya. Minimnya komputer yang terdapat di sekolah, secara tidak langsung mengharuskan para guru-guru harus mempunyai Laptop untuk mendukung kegiatan belajar mengajarnya. Dari analsis peneliti, dalam pemanfaatan Aplikasi Office oleh para guru-guru masih kurang. Hal ini dikarenakan latar belakang pendidikan para guru bukan dari teknologi informasi.

Berdasarkan pelatihan tahap ke I yang telah dilaksanakan pada tahun 2017, dengan materi Microsoft Word, hasil dari pelatihan tahap I terjadinya peningkatan kemampuan terhadap para guru khususnya kemampuan dalam menggunakan Microsoft Word (2013). Berdasarkan pembicaraan dengan Kepala Sekolah. Pihak sekolah berharap kegiatan pelatihan ini dapat dilaksanakan secara rutin setiap tahun nya.

Pada Tahap ke II ini, Peneliti berharap dapat dilaksanakannya Pelatihan Lanjutan yaitu pelatihan Microsoft Excel. Kemampuan para guru-guru di SLB Pambudi Dharma masih sangat kurang dibidang Microsoft Excel. Pemanfaatan Microsoft Excel digunakan untuk pekerjaan administrasi rutin, untuk pembuatan laporan keuangan, laporan dana BOS, dan lain sebagainya.

Pemanfaatan Teknologi Informasi dan Komunikasi (TIK) pada bidang layanan administrasi akademik di sekolah menjadi suatu kebutuhan, bukan hanya sekedar prestise atau lifestyle manajemen sekolah 
modern. Namun dalam implementasinya, banyak kendala yang ditemui sekolah dalam menerapkan TIK dalam proses pengelolaan kelembagaan ini baik faktor teknis maupun non teknis. Penguatan tata kelola, akuntabilitas dan citra publik lembaga sekolah akan bermuara pada meningkatnya kinerja lembaga sekolah dan kualitas produk. Kebijakan ini akan bermakna manakala dikaitkan dengan upaya pemenuhan layanan manajemen lembaga pendidikan yang bermutu, program pengajaran yang bermutu, fasilitas pendidikan yang bermutu,dan staf pendidikan yang bermutu pula. Ali Idrus (2014).

Penggunaan TIK dalam mendukung proses ini merupakan salah satu bentuk kepekaan lembaga sekolah dalam mencapai kesuksesan. Terkait dengan kepekaan ini, Web dan Pettigrew (Hoyt, 2007:1) menyatakan bahwa kepekaan lembaga (organizational responsiveness) merupakan isu utama yang menentukan kesuksesan dalam berusaha. Selain itu, Kuratko et. Al (2001: 44) dan Liao et. al. (2003) juga menyatakan bahwa kemampuan lembaga dalam menjawab perubahan lingkungan dunia luarnya merupakan faktor utama yang menentukan kinerja lembaga. Kepekaan organisasi membuat lembaga mampu mendeteksi secara dini perubahan pasar, merancang ulang proses transformasi yang selama ini telah berjalan dalamrangka memenuhi tuntutan pasar,berbagai informasi dengan dunia luar, mengambil keuntungan maksimal dari sistem informasi,dan lebih dahulu dalam mengadopsi proses dan produk teknologi baru dalam rangka memenangkan kompetisi. Maka dari itu, pemahaman kondisi lembaga dalam berkontribusi,mendukung, atau kemampuan merespon secara cepat dan efektif merupakan langkah kritis dalamrangka menyesuaikan dengan tuntutan lingkungannya (Daft et al., 1988).

Pada dunia pendidikan Indonesia, globalisasi memberi dampak keharusan perubahan pada cara mengajar guru yang dulunya bersifat tradisional berbasis paper menjadi kini berbasis teknologi informasi dan komunikasi (TIK). Fungsi TIK bagi guru antara lain, pertama, TIK dapat digunakan untuk membantu pekerjaan administratif (Word processor \& Kebutuhan Wajib Tingkat Dasar, Spreadsheet). Kedua, TIK dapat digunakan untuk membantu mengemas bahan ajar (Multimedia). Ketiga, TIK dapat digunakan untuk membantu proses manajemen pembelajaran. Keempat, TIK dapat digunakan untuk dukungan teknis dan meningkatkan pengetahuan agar dapat mewujudkan self running creation (antivirus, tools, jaringan, , internet, dll). (Kukuh. 2017).

Proses pelatihan dan pembinaan adalah serangkaian tahapan proses peningkatan kualitas kompetensi guru yang harus memiliki pola atau model yang lebih efektif. Model ini tidak hanya mampu secara bertahap mengarahkan peserta pelatihan pada fase kemandirian, tetapi yang terpenting adalah mendorong penyempurnaan kualitas pelatihan dan pembinaan itu sendiri ke arah yang lebih baik. Sehingga untuk dapat mencapai hal tersebut keberadaan model ini juga harus mampu merevitalisasi peran dan fungsi sekolah sebagai tempat untuk saling belajar, tumbuh dan berkembang. (Abdal, 2007).

\subsection{Permasalahan khusus yang dihadapi oleh mitra}

Dari penjabaran diatas, ada beberapa permasalahan khusus yang dihadapi oleh guru-guru SLB Pambudi Dharma, yaitu :

- Sangat jarangnya guru-guru SLB Pambudi Dharma mendapatkan pelatihan Aplikasi Komputer.

- Guru-guru SLB Pambudi Dharma masih mengalami kesulitan dalam menggunakan Microsoft Excel, untuk mengerjakan tugas-tugas administrasi sekolahan.

Berdasarkan permasalahan yang dihadapi oleh pihak SLB Pambudi Dharma, pihak Peneliti dan Pihak Mitra sepakat untuk diadakannya Pelatihan Tahap Ke II, yaitu Microsoft Excel.

\section{METODE PENELITIAN}

Pelatihan ini dirancang untuk meningkatkan prestasi kerja guru-guru SLB Pambudi Dharma, menumbuhkan motivasi untuk terus mau menulis dengan memanfaatkan teknologi informasi, terutama microsoft Excel 2013.

\subsection{Metode Pelaksanaan Kegiatan}


Pelaksanaan pelatihan ini akan dilaksanakan oleh TIM Peneliti yang mempunyai latar belakang penelitian dibidang teknologi dan informasi, yang terdiri dari 2 orang:

- Ketua tim peneliti, yang bertugas melakukan komunikasi awal, identifikasi dan analisis kebutuhan pelatihan, merumuskan sasaran atau tujuan pelatihan, mempersiapkan materi pelatihan dan ikut serta dalam penyampaian materi atau implementasi

- Anggota Peneliti, mempunyai tugas mempersiapkan materi pelatihan dan implementasi.

\subsection{Kegiatan}

Kegiatan pelatihan ini dilaksanakan di ruang sebaguna di SLB Pambudi Dharma yang berlokasi di Jl. Kolonel Masturi Cimahi. Pelatihan akan menggunakan salah satu ruang kelas yang disediakan oleh pihak Sekolah.

\section{Pra Pelatihan}

Pada tahap ini, peneliti melakukan analisa kebutuhan. Analisa kebutuhan dilakukan agar pelatihan yang dilaksanakan dipersiapkan secara matang. Ada beberapa permasalahan pokok yang didapat dari hasil analisa, diantaranya adalah :

- Peserta pelatihan lebih mengharapkan ada materi yang secara khusus yang berhubungan langsung dengan aktivitas peserta. Misalnya dalam mengelola data keuangan ataupun pelaporan yang secara rutin di kerjakan peserta setiap periodenya.

- Setelah selesai pelatihan, peserta mengharapkan ada bantuan jika peserta mengalami kesulitan dalam menerapkan hasil pelatihan mengerjakan aktivitas mereka.

- Perlu dibentuknya kelompok-kelompok kecil agar peserta dapat bekerjasama dalam melaksanakan pelatihan. Hal ini dikarenakan waktu dan tenaga peneliti yang terbatas. Pada kenyataannya masih banyak peserta yang belum memahami aplikasi komputer atau jarang menggunakan komputer. Kemungkinan jarangnya menggunakan komputer, dikarenakan beberapa orang peserta tidak ditugaskan ke pekerjaan administrasi sekolah.

Kegiatan selanjutnya adalah peneliti bersama kepala sekolah melakukan diskusi kecil untuk mempersiapkan sarana lainnya seperti ruangan pelatihan, fasilitas pelatihan lainnya. Pelaksanaan pelatihan dilaksanakan di sekolah dengan ruangan yang berukuran $\pm 5 \mathrm{~m}$ x 20m, karena di Sekolah Luar Biasa umumnya ruang kelasnya tidak luas. Sedangkan fasilitas penyampaian materi seperti proyektor, pihak sekolah sudah mempersiapkannya.

Setelah analisa kebutuhan dilaksanakan, peneliti melakukan rapat kecil dengan tim peneliti untuk mengatur proses pelaksanaan dalam pelaksanaan pelatihan. Strategy dimaksud agar materi ataupun cara penyamapaian pelatihan dapat sesuai dengan kebutuhan peserta, seperti perlunya dilakukan test awal untuk mengatahui lebih rinci kemampuan peserta sebelum mengikuti pelatihan. Antara test awal dan test akhir dapat dijadikan keberhasilan peserta setelah mengikuti proses pelatihan ini.

\section{Pelaksanaan Pelatihan.}

Dalam pelaksanaan pelatihan, peneliti melakukan implementasi berdasarkan dari hasil analisis dan identifikasi yang telah dilakukan pada tahap Pra Pelatihan. Sebelum pelatihan dimulai, dilakukan test awal terhadap peserta pelatihan. Test awal ini bersifat secara umum membahas microsoft Excel secara umum, tanpa keterkaitan dengan aktivitas peserta sehari-hari.

Pada hari pertama pelatihan ini, materi yang dibahas seperti Pengantar komputer. Pengantar komputer berisi cara mengelola file seperti membuat folder penyimpanan fila latihan, cara menduplikat file dan lain-lain. Pengantar ini berguna bagi yang belum menguasai komputer secara umum. Kemudian dilanjutkan dengan pengantar Microsoft Excel secara umum, yaitu bagai mana membuka microsoft 
excel, kemudian bagaimana menyimpan file pelatihan ke dalam folder yang telah dibuat, dan lain-lain. Selanjutnya diteruskan dengan materi-materi dasar Microsoft Excel seperti bagaimana mengelola cell, coulum, dan seterusnya. Setelah selesai pelatihan dihari pertama, dilanjutkan dengan tanya jawab antara peserta dengan instruktur pelatihan. Tanya jawab ini masih seputar pengetahuan excel secara umum, belum membahas tentang materi yang berhubungan dengan aktivitas peserta. Latihan kasus akan dilaksanakan pada hari kedua, yaitu membahas tentang permasalahan yang dihadapi oleh peserta dalam menyelesaikan pekerjaannya.

Pelatihan di hari kedua peserta mulai mengutarakan permasalahan yang mereka hadapi sewaktu mengerjakan pekerjaan mereka sehari-hari. Pada sesi ini peserta menceritakan seperti apa kesulitan yang mereka alami. Kemudian instruktur memberikan contoh kasus yang mirip seperti permasalahan peserta dan dibahas atau dikerjakan secara bersamaan.

Pada akhir hari kedua ini, instruktur memberikan sebuah soal Microsoft Excel untuk dijadikan bahan evaluasi dari kegiatan pelatihan ini. Hasil dari latihan soal ini akan di bandingkan dengan hasil test awal agar dapat menjadi bahan perbandingan untuk mengambil kesimpulan apakah selama dalam mengikuti kegiatan ini peserta mengalami peningkatan dari sebelumnya.

\section{Pasca Pelatihan.}

Pada tahap pasca pelatihan ini, sebelum penutupan peserta dan instruktur juga pimpinan sekolah melakukan diskusi kecil membahas proses pelatihan yang telah dilaksanakan. Kegiatan pelatihan ini sangat baik dilakukan dan untuk kedepannya kegiatan ini dapat lebih di tingkatkan lagi.

\section{HASIL DAN PEMBAHASAN 3.1 Hasil Kegiatan}

Dari proses kegiatan pelatihan yang telah dilaksanakan di Sekolah Luar Biasa Pambudi Dharma selama dua hari, berdampak bagi peserta pelatihan, pihak seolah maupun untuk peneliti itu sendiri.

\subsection{Hasil Bagi Peserta}

Berdasarkan hasil dari diskusi dengan pihak sekolah pada saat pasaca pelatihan, pihak sekolah merasakan dampak dari hasil pelatihan. Peserta sudah memahami bagaimana cara menggunakan Microsoft Excel untuk aktivitas mereka walaupun belum di praktekan ke pekerjaan langsung, tapi setidaknya sudah pernah di coba pada saat kegiatan pelatihan. Peserta juga berterimakasih karena pihak penyelenggara bersedia membantu jika pihak sekolah mengalami kesulitan dalam melaksanakan aktivitasnya nanti.

\subsection{Sekolah}

Manfaat yang didapat dari kegiatan pelatihan ini adalah pihak sekolah ternbantu dalam peningkatan pengetahuan guru-guru dalam bidang komputer. Peningkatan kemampuan guru-guru ini dapat membantu guru dalam menyelesaikan aktivitas ataupun untuk kepentingan murid dan guru secara pribadi. Dengan terbentuknya suatu modul panduan Microsoft Excel, pihak sekolah dapat memanfaatkannya pada saat membutuhkan.

\section{KESIMPULAN}

Berdasarkan hasil dari kegiatan pelatihan yang telah dilaksanakan, maka kesimpulan yang dapat diambil adalah sebagai berikut :

- Dengan diadakannya pelatihani ini, maka guru-guru mengalami peningkatan dalam penguasaan komputer terutama microsoft Excel.

- Aktivitas guru dalam menyelesaikan permasalahan di sekolah dapat teratasi

- Pelatihan ini dapat membantu guru dalam penulisan karya ilmiah 
- Terbentuknya suatu modul penggunaan microsoft excel yang berkaitan dengan aktivitas sekolah

\section{REFERENSI}

1. Hernawan Sulistyanto (2017) PAKOM Pelatihan Pengoperasian Komputer Bagi Perangkat Desa di Kecamatan Gondangrejo Kabupaten Karanganyar. Warta LPM, Vol. 20, No. 2, September 2017: 111-114.

2. Yusril Ikhwani (dkk) (2015). Pelatihan Aplikasi Microsoft Word 2013 Pada SMP H. A. Johansyah A Banjarmasin. Jurnal Al-Ikhlas, Volume 1 Nomor 1, Oktober 2015.

3. Sindu Setiyawan, (2014). Deskripsi Kemampuan Guru SD Negeri Bakulan Dalam Menulis Karya Ilmiah Sebagai Pengembangan Profesi. Skripsi.

4. Budi Usodo (2016). Pelatihan Penerapan beberapa Aplikasi dari Microsoft dalam Pembelajaran Bagi Guru-Guru Matematika SMA di Kabupaten Sragen. Jurnal Elektronik Pembelajaran Matematika, Vol. 4, No.9, Hal 743-752 November 2016.

5. Agus Triyanto (2010). Implikasi Perkembangan Tenologi Komputer dan Internet Bagi Konselor Sekolah. Paradigma No.09 Th. V Januari 2010, ISSN 1907-297X.

6. Modul Micosoft Excel, Team Lab Komputer DPP Infokom tahun 201. 